\title{
Mechanical Properties of Recycled Kraft Paper Residue Polyester Composites
}

\author{
João Marciano Laredo dos Reis ${ }^{\mathrm{a} *}$, José Luiz Cardoso ${ }^{\mathrm{b}}$, Protasio Ferreira e Castro ${ }^{\mathrm{b}}$ \\ ${ }^{a}$ Theoretical and Applied Mechanics Laboratory - LMTA, Mechanical Engineering Post Graduate \\ Program-PGMEC, Universidade Federal Fluminense - UFF, Rua Passo da Pátria, 156, \\ CEP 24210-240, Niteroi, RJ, Brazil \\ ${ }^{b}$ Civil Engineering Post Graduate Program - POSCIVIL, Universidade Federal Fluminense - UFF, \\ Rua Passo da Pátria, 156, CEP 24210-240, Niteroi, RJ, Brazil
}

Received: October 11, 2013; Revised: April 29, 2014

\begin{abstract}
Construction industry has a significant grow in the past few years. Following that rate, the amount of residue produced from that growth also increases. The need to find alternatives apart from disposing that residue in landfills have led researchers to find new materials from disposal residues. In this paper, kraft paper from cement bags used in building constructions is utilized as reinforcement in unsaturated polyester matrix composites. The kraft paper residue (KPR) was used as shredded particles in different quantities, $30 \%, 40 \%$ and $50 \%$, by weight, and also cutted in sheets to be used as laminas. Tensile and flexural tests were performed to characterize the KPR composites. The results showed that tensile strength and modulus of elasticity increase as shredded KPR content increase. Higher increase was observed when KPR laminas were used as reinforcement. In flexion, a decrease is reported when shredded KPR is used but an increase was observed due to KPR laminas. Flexural modulus was not altered by KPR.
\end{abstract}

Keywords: recycling, Kraft paper, composites, mechanical properties

\section{Introduction}

In the last decades recycling, reusing and recovering cellulosic fibers have considerably increased. Cellulosic fibers, like wood, sisal, coconut fiber (coir), jute, palm, bamboo, wood, paper in their natural condition, as well as, several waste cellulosic products such as shell flour, wood flour and pulp have been used as reinforcement agents of different thermosetting and thermoplastic resins ${ }^{1-8}$. Global production of cellulosic fibers (wood pulp) in 2012 was 173.8 million tonnes ${ }^{9}$. Chemical pulp made up $93 \%$ of market pulp ${ }^{10}$. From these values, it can be observed that the availability of this raw material is really important and their importance will grow when the consumption per capita of paper in developing countries achieves comparable values to developed countries.

Kraft paper is paper from wood pulp manufactured by the Kraft process. The manufacturing process involves pulverizing the wood pulp and blending the material into large sheets of strong brown wood filament ${ }^{11}$.

One of the main applications of Kraft papers is cement containers (bags) ${ }^{12}$. Most of the cement bags used in civil construction every year are disposed without any treatment, having associated an enormous negative environmental impact. This residue cannot be treated since has a significant quantity of cement dust impregnated and therefore cannot be recycled into cellulose fibers. For example, in 2010 the cement production in Brazil reached 59 million tonnes. Of this production, $78 \%$ was bagged, which is equivalent to 920 million cement bags $(50 \mathrm{~kg})^{13}$.

*e-mail: jreis@mec.uff.br
The fibers of these cement bags have excellent mechanical and physical properties. There is great potential on its reuse for the production of new composite materials. Plant and vegetable fibers have been used extensively to improve the mechanical properties of components whose raw material are fibers ${ }^{14-20}$.

Every recycling process needs energy to transform residue and insert it in the manufacturing process again. This amount of energy is related to the final proposed product ${ }^{21}$. In some situations the recycling process generates raw material that in some cases causes higher environmental damage than waste disposal. In this particular case the recycling processes were shredding, which produces no hazardous contaminant and cutting the cement sacks in sheets producing laminas.

In this study, KPR (recycled softwood fibers) coming from used cement sacks was used as reinforcement for the preparation of unsaturated polyester polymer composites. Composites comprising 30,40 and $50 \mathrm{wt}$.\% of reinforcement and laminates from cutted sheets were manufactured and tested. The mechanical properties (tensile and flexural) of the obtained composites were also analyzed.

\section{Material and Methods}

\subsection{Material}

The cleaning process of cement sacks starts by removing any solid grain, residue from cement hydration to avoid any damage in the shred machine. Since there is more cement residue in the bottom and in the fold of the bags, 60 


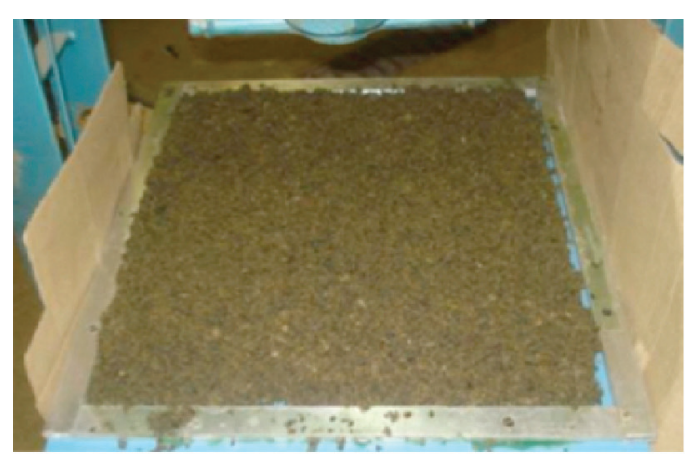

(a)

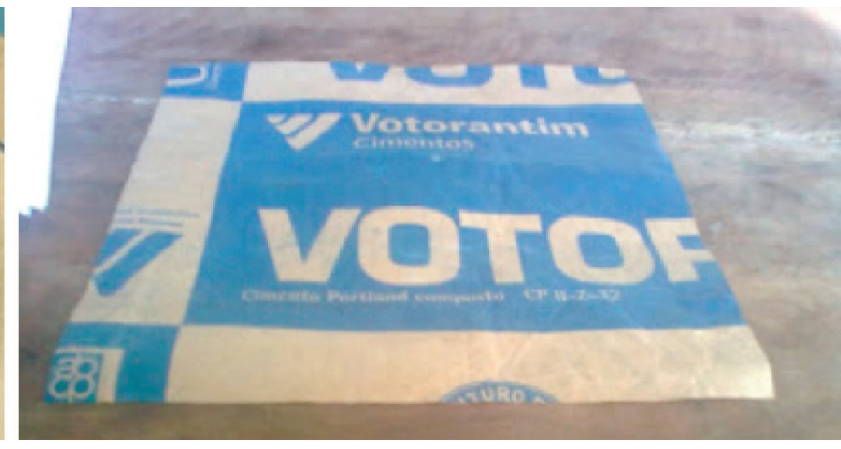

(b)

Figure 1. Kraft paper residue: Shredded and lamina.

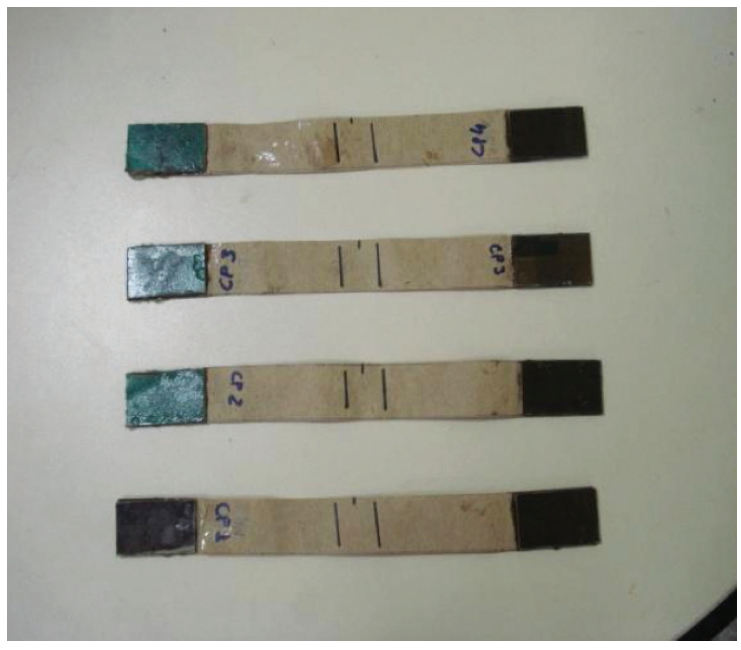

Figure 2. Kraft paper lamina specimen.

samples were weight and then concluded that in average the cement sacks carries $110 \mathrm{~g}$ of cement when disposed. This is equivalent to $0,22 \%$ of the initial weight and therefore $100 \mathrm{k}$ tonnes of cement ( 2 million sacks) can be disposed in landfill.

Two processes were carried out in order to utilized KPR from used cement bags. First, the cement sacks were cutted in small pieces and then shredded in order to produce small particles, $5 \mathrm{~mm}$ in average. The second was to cut the bags in sheets to produce a $300 \times 300 \mathrm{~mm}$ lamina. Cement bags laminas had $80 \mathrm{~g} / \mathrm{m}^{2}$. Figure 1 displays the shredded cement bags disposed in the mold (a) and the cement bag lamina (b).

KPR laminas were tested according to ASTM D $638^{22}$ in order to determine the mechanical properties. Figure 2 presents the KPR lamina specimen.

Cement bags lamina displayed a maximum tensile strength of $34.5 \pm 3 \mathrm{MPa}$ and a strain at failure $8.4 \% \pm 0.4 \%$.

The polyester resin used in this investigation was an unsaturated polyester manufactured by recycled PET, product commercialized by Reichhold ${ }^{\circledR}$. The resin system is pre-accelerated by the manufacturer and the initiator used was methyl ethyl ketone peroxide ( $2 \mathrm{phr}$ ). Unsaturated polyester resin properties provided by the manufacturer are presented in Table 1.
Table 1. Unsaturated polyester resin properties.

\begin{tabular}{lc}
\hline \multicolumn{1}{c}{ Property } & Polyester \\
\hline Viscosity at $250 \mathrm{C} \mu(\mathrm{cP})$ & $250-350$ \\
Density $\rho\left(\mathrm{g} / \mathrm{cm}^{3}\right)$ & 1.09 \\
Heat Distortion Temperature HDT $\left({ }^{\circ} \mathrm{C}\right)$ & 85 \\
Modulus of Elasticity E $(\mathrm{GPa})$ & 3.3 \\
Flexural Strength $(\mathrm{MPa})$ & 45 \\
Tensile Strength $(\mathrm{MPa})$ & 40 \\
Maximum Elongation $(\%)$ & 1 \\
\hline
\end{tabular}

\subsection{Methods}

Composites with shredded KPR were fabricated with 30,40 and $50 \mathrm{wt} \%$ contents with unsaturated polyester resin using a compact mold producing composite sheets with $350 \mathrm{~mm} \times 150 \mathrm{~mm} \times 2.5 \mathrm{~mm}$. KPR shredded pieces were mixed with the unsaturated polyester resin in a planetary mixer for 5 minutes to obtain a homogenized mixture and then placed in the steel mold. Composites were left to cure for 24 hours in room temperature. Hand lay-up laminates with KPR sheets were also produced, resulting in composite plates with $300 \mathrm{~mm} \times 300 \mathrm{~mm} \times 3 \mathrm{~mm}$. KPR sheets, 6 in total, were positioned manually in the steel open mold, and resin was brushed into the KPR plies. Entrapped air was removed manually with rollers to complete the laminates structure. Also, laminate composites were left to cure for 24 hours in room temperature. Specimens were cut according to ASTM D $638^{22}$ and ASTM D $790^{23}$ in order to produce tensile and three point bending samples, respectively. The specimens were then tested using an Shimadzu AG-X 100 universal testing machine operated at a cross-head speed of $5 \mathrm{~mm} / \mathrm{min}$ for tensile and $2 \mathrm{~mm} / \mathrm{min}$ for bending. A DVE, digital video extensometer, was used to measure the strain. Five specimens were tested for each batch. Figure 3 presents the tensile and flexural test set-ups.

\section{Results and Discussion}

\subsection{Tensile tests}

Tensile test results of KPR composites with 30, 40 and $50 \mathrm{wt} \%$ content and KPR laminates are presented in Table 2. 

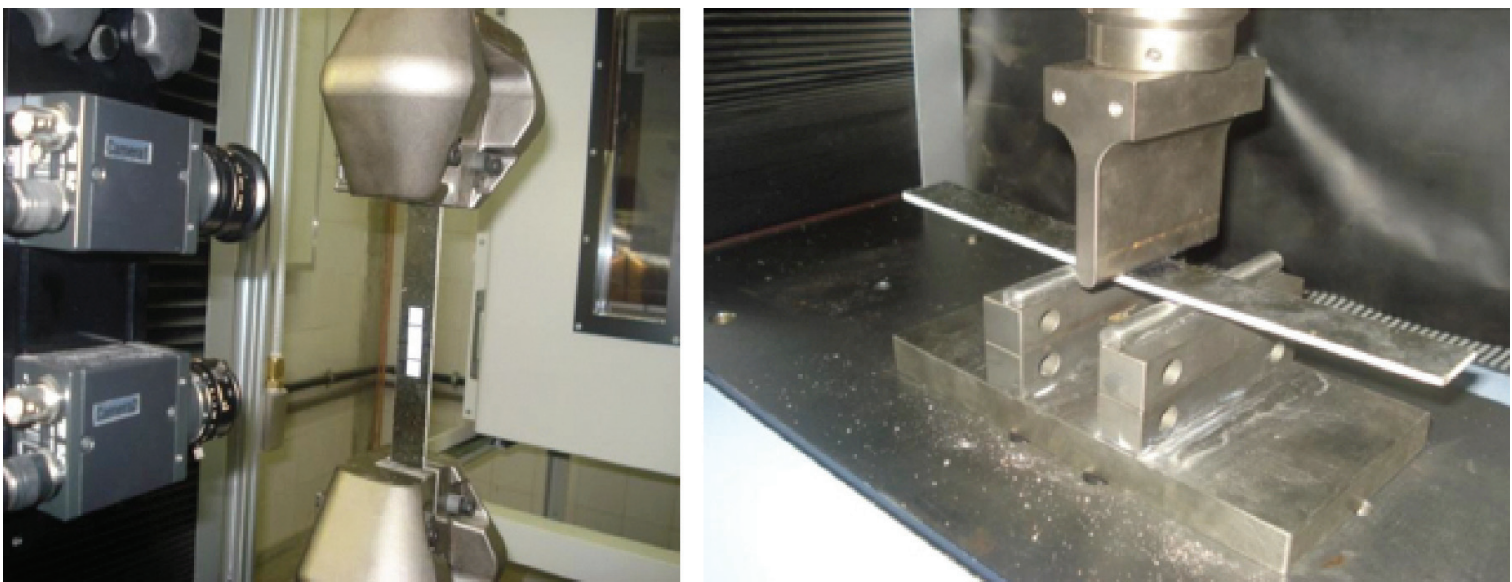

Figure 3. Tensile and flexural test set-up of KPR composites.

Table 2. Tensile test results of KPR composites.

\begin{tabular}{ccc}
\hline$\%$ Kraft residue & $\begin{array}{c}\text { Ultimate tensile } \\
\text { strength }(\mathbf{M P a})\end{array}$ & $\begin{array}{c}\text { Tensile modulus of } \\
\text { elasticity }(\mathbf{G P a})\end{array}$ \\
\hline 0 & $13.30 \pm 0.67$ & $2.93 \pm 0.42$ \\
30 & $20.91 \pm 1.92$ & $3.35 \pm 0.89$ \\
40 & $21.86 \pm 2.11$ & $3.43 \pm 0.53$ \\
50 & $23.37 \pm 1.20$ & $3.44 \pm 0.28$ \\
Laminate & $65.95 \pm 1.23$ & $46.17 \pm 3.77$ \\
\hline
\end{tabular}

According to Table 2 it can be seen that shredded KPR, known for having a hydrophilic nature, reinforces unsaturated polyester resin, which has essentially a hydrophobic characteristics. Introducing $30 \%$ of KPR increase $57.2 \%$ the ultimate tensile strength and $14.3 \%$ the modulus of elasticity. Increasing shredded KPR increases ultimate tensile strength and modulus of elasticity. When KPR content increases to $40 \%$, ultimate tensile strength elevates $64.4 \%$ and $17.1 \%$ higher modulus of elasticity is observed. $50 \%$ content of KPR elevates $75.7 \%$ the ultimate tensile strength and $17.4 \%$ the modulus of elasticity. The difference observed between composites with $30 \%$ and $50 \%$ of KPR is very small, inside the standard deviation results, producing no significant gap. As expected, KPR composites manufactured with KPR laminas produce higher tensile strength and stiffness, since load transfer between particles reinforcement are weaker than laminates. $495.9 \%$ higher ultimate tensile strength and $1575.8 \%$ increase in the modulus of elasticity is observed when compared to plain unsaturated polyester resin. Comparing to $50 \%$ content of shredded KPR an elevation of $282.2 \%$ in the tensile strength and $1342.1 \%$ in the modulus of elasticity is calculated. The stress transfer efficiency in composite materials is related with adhesion at interface and good compatibility. Also, surface roughness contributes to increase mechanical anchoring and therefore reinforcement effect and stress transfer in the composite. In this case, since no coupling agent was used no covalent bonding can take place at fibermatrix interface. Figure 4 presents the typical tensile stress vs. strain curves of KPR composites.

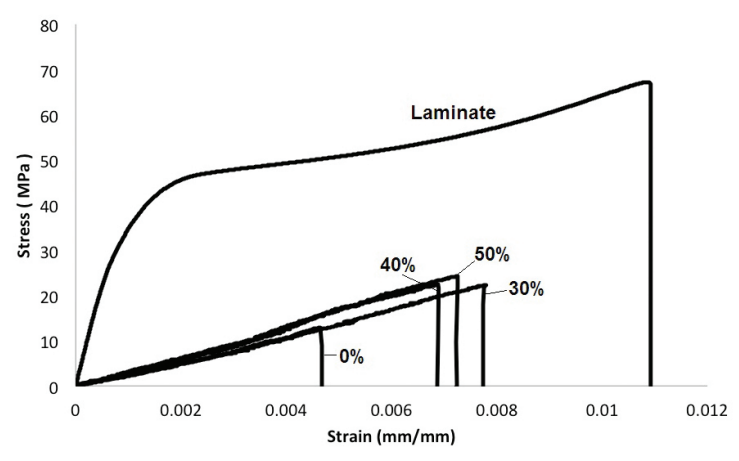

Figure 4. Typical tensile stress vs. strain of KPR composites.

From Figure 4 it can be seen that unsaturated polyester resin and KPR composites manufactured with shredded KPR displays and brittle behavior. This was expected since particle reinforced composites have low stiffness ${ }^{24}$. KPR laminate composites displayed higher stiffness and strain at failure. Similar results can be found when chopped and woven glass fibers reinforced unsaturated polyester composites are tested in tension ${ }^{25}$. The interaction mechanism is established looking at the surface morphology of KPR displayed in Figure 5. The microphotography corresponds to a fractured tensile specimen with $50 \%$ of shredded KPR, from which the roughness of the fiber surface is illustrated.

It can be seen in Figure 5 a gap between the fiber and the matrix indicating a non-effective adhesion at fiber-matrix interface can be established. However, some mechanical linkage was possible between the composite constituents analyzing the fiber fracture. The inter-diffusion of the unsaturated polyester on the surface of the reinforcement is helped by the irregular topography of KPR fibers ${ }^{26}$.

\subsection{Flexural tests}

Three point bending flexural test results performed in the composites manufactured with 30, 40 and 50 wt $\%$ content of KPR and KPR laminas are presented in Table 3.

From Table 3 it is clear that in flexion shredded KPR does not reinforce the unsaturated polyester matrix. A decrease of 


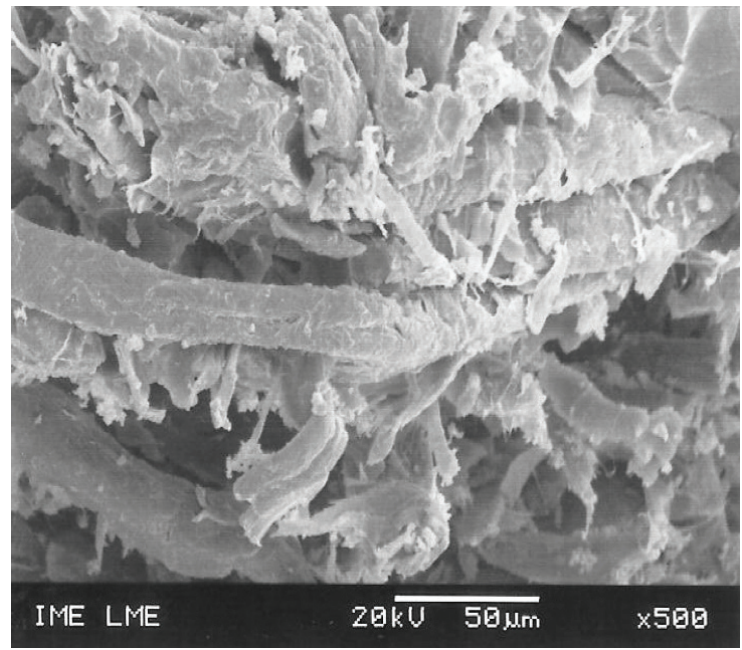

Figure 5. SEM microphotography of the fractured surface of KPR/ polyester composites.

Table 3. Flexural test results of KPR composites.

\begin{tabular}{lcc}
\hline \% Kraft residue & $\begin{array}{c}\text { Flexural strength } \\
(\mathbf{M P a})\end{array}$ & $\begin{array}{c}\text { Flexural modulus } \\
\text { of elasticity }(\mathbf{G P a})\end{array}$ \\
\hline 0 & $61.76 \pm 1.15$ & $4.55 \pm 0.08$ \\
30 & $44.35 \pm 3.20$ & $4.66 \pm 0.07$ \\
40 & $46.24 \pm 3.11$ & $4.71 \pm 0.48$ \\
50 & $57.85 \pm 2.76$ & $4.95 \pm 0.44$ \\
Laminate & $104.47 \pm 8.40$ & $4.99 \pm 0.36$ \\
\hline
\end{tabular}

$28.2 \%$ is observed when $30 \%$ of shredded KPR is used. Similar behavior is reported for $40 \% \mathrm{KPR}$ content, $25.1 \%$ lower flexural strength and for $50 \%$ of shredded KPR content a decrease of $6.3 \%$ is calculated. As observed in tension, the composites made with KPR laminas produce higher flexural strength compared to the unreinforced matrix, an increase of $69.2 \%$ is calculated. It was noticed that fibre-matrix interface produced no increase in strength. Despite of the decrease of flexural strength, stiffness remains unaltered, considering the standard deviation. Within the experimental errors it can be said that flexural modulus of elasticity are basically equal. A slight increase is calculated for $50 \%$ shredded KPR and laminate composites when compared to unreinforced polyester matrix. Figure 6 presents the typical flexural stress vs. strain curves of KPR composites.

From Figure 6 it can be seen that no significant change is observed in stiffness. As KPR is introduced in the composite mixture soften failure is reported and therefore less brittle. Also, strain at failure occurs at higher levels. Failure observed in the composites manufactured with the KPR laminas occur by delamination. Since KPR has large quantities of cement it was expected that the composites manufactured with laminas have poor fiber/matrix adhesion and therefore failure by delamination, as it can be seen in Figure 7. The interface failure was mainly a frictional type failure.

\section{Conclusions}

The mechanical, tensile and flexural properties of KPR from cement bags were evaluated. This was performed

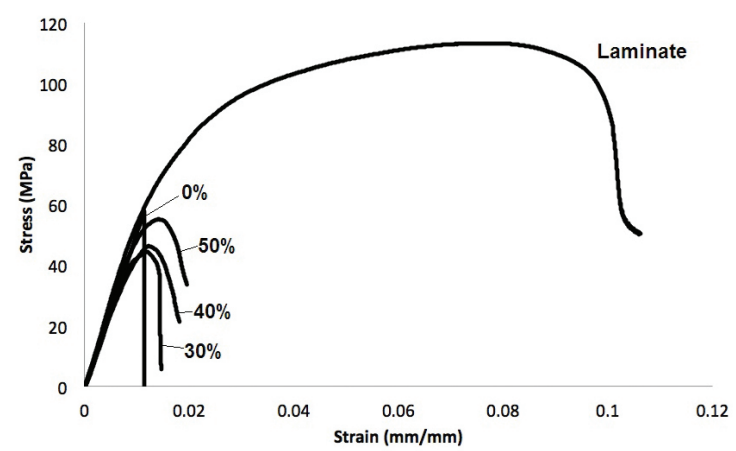

Figure 6. Typical flexural stress vs. strain of KPR composites.

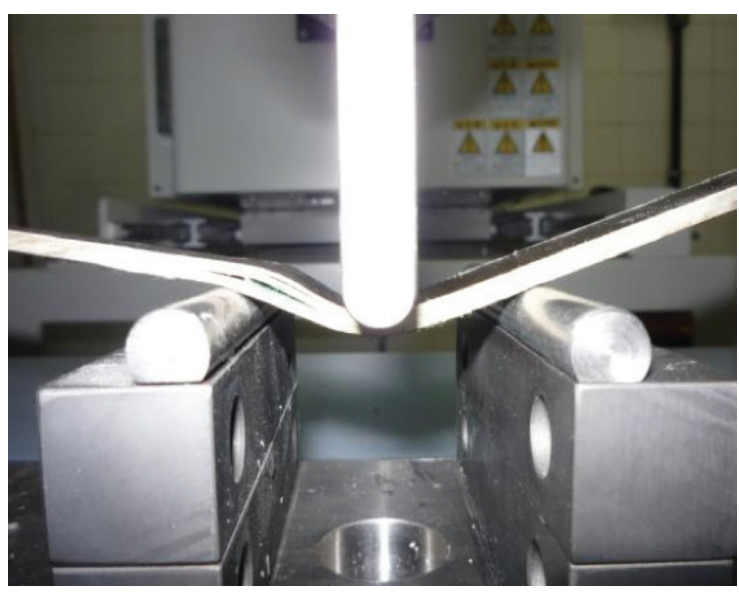

Figure 7. Failure mode of KPR laminates three point bending flexural tests.

using different quantities, 30, 40 and 50 wt.\% of shredded KPR and cutted lamina sheets as fiber reinforcement in unsaturated polyester matrix composites. The fiber-matrix interaction were changed by modifying the type of fibers, first to increase the quantity of shredded fibers to further expose the cellulose microfibrils and then to improve fiber wetting and impregnation. The main ways to explain the strengthening of the composite is related to the mechanical anchoring, adhesion mechanism at fiber-matrix interface, and Van der Waals. In tension the use of shredded KPR increases both ultimate strength and modulus of elasticity. The increase in the mechanical properties using KPR laminas is even higher. In flexion no reinforcement was observed when shredded KPR was used. Flexural strength decreases but statistically no variation in the flexural modulus of elasticity was reported. Shredded KPR contributes to less brittle failure. Again, composites made with KPR laminas displayed a significant increase in the flexural strength.

\section{Acknowledgments}

The financial support of FAPERJ (Rio de Janeiro State Funding) and CNPq (Research and Teaching National Council) are gratefully acknowledged. 


\section{References}

1. George J, Sreekala MS and Thomas S. A review on interface modification and characterization of natural fibre reinforced plastic composites. Polymer Engineering Science. 2001; 41:1471-85. http://dx.doi.org/10.1002/ pen. 10846

2. Varghese S, Kuriakose B and Thomas S. Stress relaxation in short sisal fibre-reinforced natural rubber composites. Journal of Applied Polymer Science. 1994; 53:1051-60. http://dx.doi. org/10.1002/app.1994.070530807

3. Ahlblad G, Kron A and Stenberg B. Effects of plasma treatment on mechanical properties of rubber/cellulose fibre composites. Polymer International. 1994; 33:103-9. http:// dx.doi.org/10.1002/pi.1994.210330112

4. Geethamma VG, Joseph R and Thomas S. Short coir fibre-reinforced natural rubber composites: effects of fibre length, orientation and alkali treatment. Journal of Applied Polymer Science. 1995; 55:583-94. http://dx.doi.org/10.1002/ app.1995.070550405

5. Hornsby PR, Hinrichsen E and Tarverdi K. Preparation and properties of polypropylene composites reinforced with wheat and flax straw fibres. Part II analysis of composite microstructure and mechanical properties. Journal of Materials Science. 1997; 32:1009-15. http://dx.doi. org/10.1023/A:1018578322498

6. MiY,Chen X and Guo Q. Bamboo fibre-reinforced polypropylene composites: crystallization and interfacial morphology. Journal of Applied Polymer Science. 1997; 64:1267-73. http://dx.doi. org/10.1002/(SICI)1097-4628(19970516)64:7<1267::AIDAPP4>3.0.CO;2-H

7. Coutinho FMB, Costa THS and Carvalho DL. Polypropylenewood fibre composites: effect of treatment and mixing conditions on mechanical properties. Journal of Applied Polymer Science. 1997; 65:1227-35. http://dx.doi. org/10.1002/(SICI)1097-4628(19970808)65:6<1227::AIDAPP18>3.0.CO;2-Q

8. Oksman $\mathrm{K}$, Lindberg $\mathrm{H}$ and Holmgren $\mathrm{A}$. The nature and location of SEBS-MA compatibilizer in polyethylenewood flour composites. Journal of Applied Polymer Science. 1998; 69:201-9. http://dx.doi.org/10.1002/(SICI)10974628(19980705)69:1<201::AID-APP23>3.0.CO;2-0

9. Food and Agricultural Organization of the United Nations - FAO. ForesSTAT database on website. [latest access on 28/01/2014].

10. Overview of the Wood Pulp Industry. Market Pulp Association. 2007. Retrieved 2007-10-13.

11. Barroti SLB. Celulose e Papel - tecnologia de Fabricação do Papel. Instituto de Pesquisas Tecnológicas do estado de São Paulo (IPT). 1988; 1:848-849.

12. Buson MA. KRAFTTERRA: Desenvolvimento e análise preliminar do desempenho técnico de componentes de terra com a incorporação de fibras de papel kraft provenientes da reciclagem de sacos de cimento para vedação vertical [Tese]. Brasília: Universidade de Brasília; 2009. PMid:19965378.

13. Sindicato Nacional da Indústria do Cimento. SNIC 2010 annual report. Available from: <http://www.snic.org.br/>.
14. Larotonda FDS, Matsui KN, Sobral PJA and Laurindo JB. Hygroscopicity and water vapor permeability of Kraft paper impregnated with starch acetate. Journal of Food Engineering. 2005; 71:394-402. http://dx.doi.org/10.1016/j. jfoodeng.2004.11.002

15. Matsui KN, Larotonda FDS, Paes SS, Luiz DB, Pires ATN and Laurindo JB. Cassava bagasse-Kraft paper composites: analysis of influence of impregnation with starch acetate on tensile strength and water absorption properties. Carbohydrate Polymers. 2004; 55:237-243. http://dx.doi.org/10.1016/j. carbpol.2003.07.007

16. $\mathrm{KuH}$, Wang H, Pattarachaiyakoop $\mathrm{N}$ and Trada M. A review on the tensile properties of natural fiber reinforced polymer composites. Composites Part B: Engineering. 2011; 42:856- 873. http:// dx.doi.org/10.1016/j.compositesb.2011.01.010

17. Pacheco-Torgal $\mathrm{F}$ and Jalali S. Cementitious building materials reinforced with vegetable fibres: A review. Construction and Building Materials. 2011; 25:575-581. http://dx.doi. org/10.1016/j.conbuildmat.2010.07.024

18. Shalwan A and Yousif BF. In State of Art: Mechanical and tribological behaviour of polymeric composites based on natural fibres. Materials \& Design. 2013; 48:14-24. http:// dx.doi.org/10.1016/j.matdes.2012.07.014

19. Xie Y, Hill CAS, Xiao Z, Militz H and Mai C. Silane coupling agents used for natural fiber/polymer composites: A review. Composites Part A: Applied Science and Manufacturing. 2010; 41:806-819. http://dx.doi.org/10.1016/j. compositesa.2010.03.005

20. Herrera-Franco PJ and Valadez-González A. Mechanical properties of continuous natural fibre-reinforced polymer composites. Composites Part A: Applied Science and Manufacturing. 2004; 35:339-345. http://dx.doi.org/10.1016/j. compositesa.2003.09.012

21. Laurijssen J, Marsidi M, Westenbroek A, Worrell E and Faaij A. Paper and biomass for energy?: The impact of paper recycling on energy and $\mathrm{CO}_{2}$ emissions. Resources, Conservation and Recycling. 2010; 54:1208-1218. http://dx.doi.org/10.1016/j. resconrec.2010.03.016

22. American Society for Testing and Materials. ASTM D638-10: Standard Test Method for Tensile Properties of Plastics. 2010.

23. American Society for Testing and Materials. ASTM D79010: Standard Test Methods for Flexural Properties of Unreinforced and Reinforced Plastics and Electrical Insulating Materials. 2010.

24. Hull D and Clyne TW. An Introduction to Composite Materials. Cambridge: Cambridge University Press; 1996. http://dx.doi. org/10.1017/CBO9781139170130

25. Varga C, Miskolczi N, Bartha L and Lipóczi G. Improving the mechanical properties of glass-fibre-reinforced polyester composites by modification of fibre surface. Materials \& Design. 2010; 31:185-193. http://dx.doi.org/10.1016/j. matdes.2009.06.034

26. Vilaseca F, Méndez JA, López JP, Vallejos ME, Barberà L, Pèlach MA et al. Recovered and recycled Kraft fibers as reinforcement of PP composites. Chemical Engineering Journal. 2008; 138:586-595. http://dx.doi.org/10.1016/j. cej.2007.07.066 